\title{
Krzysztof Łukaszuk
}

Bank Spółdzielczy w Bielsku Podlaskim

\section{Rozwój bankowości spółdzielczej w Polsce}

\begin{abstract}
Streszczenie. Najstarsza gałąź spółdzielczości w Polsce (bankowa) funkcjonuje od 1861 roku. Powstała z inicjatyw duchowieństwa, aby poprawić sytuację chłopów i chronić ich interesy oraz walczyć z wyzyskiem ekonomicznym i lichwą. W okresie zaborów, skupiając członków w swych szeregach, obok celów ekonomicznych wspierała także obronę i wzmacnianie polskości. Stopniowo rozwijała się do wybuchu pierwszej wojny światowej, nieco wolniej w okresie odrodzenia Polski i dwudziestoleciu międzywojennym. Druga wojna światowa przyniosła likwidację spółdzielni oraz ich majątków i dopiero powojenne gruntowne reformy gospodarcze i prawne umożliwiły ponowne ich odradzanie się, które trwało aż do lat 70., gdy centralizacja ponownie wymusiła zmiany sektora. Lata 90. to nowe podstawy prawne konstrukcji nowoczesnego systemu bankowego w Polsce, jednakże okupione licznymi konsolidacjami i drastycznym spadkiem liczby banków spółdzielczych. Współcześnie spółdzielczość bankowa zmaga się z rosnącymi wymogami kapitałowymi i technologicznymi oraz z narastającą konkurencją i wyborem odpowiedniego modelu biznesowego. Mimo upływu lat nadal zachowuje swoją aktualność, a w porównaniu z pozostałymi podmiotami okazała się bardziej odporna na globalny kryzys finansowy i wpłynęła stabilizująco na system finansowy kraju.
\end{abstract}

Słowa kluczowe: bank spółdzielczy, historia bankowości spółdzielczej, spółdzielnie oszczędnościowo-pożyczkowe, spółdzielnie kredytowe

\section{Wstęp}

Początki bankowości spółdzielczej to włoskie banki pobożne, które zaczęły rozwijać się w różnych częściach Europy. Pierwsze wzmianki dotyczące polskiej spółdzielczości bankowej pojawiły się w XVI wieku, a początki pierwszych polskich spółdzielni oszczędnościowo-kredytowych datuje się na lata 60. XIX wieku. Celem organizacji było wspieranie członków społeczności lokalnej w zakresie finansowym poprzez udzielanie mikrokredytów. Fundusze pozyskiwano głównie od duchowieństwa, zatem zgodnie z nauką Kościoła katolickiego była to działalność non profit.

Jednak najszybszy rozwój bankowości spółdzielczej nastąpił w XIX wieku na ziemiach niemieckich. Liczne sytuacje kryzysowe (susze, powodzie) wywołały oddolną inicjatywę spółdzielni kredytowych jako przeciwwagi dla dynamicznie rozwijającego się

\footnotetext{
${ }_{\text {krzysztof.lukaszuk@wp.pl }}$
} 
agresywnego kapitalizmu powodującego zubożenie niższych warstw społecznych (zwłaszcza ludności wiejskiej). Nowopowstałe spółdzielnie udzielały niskooprocentowanych pożyczek członkom tych instytucji na wznowienie produkcji czy usunięcie skutków klęsk. Za dwóch głównych prekursorów ruchu spółdzielczego w Niemczech uznaje się Hermanna Schulzego-Delitzschego oraz Friedricha Wilhelma Raiffeisena.

Celem opracowania jest przybliżenie osobom zainteresowanym lokalnych podmiotów sektora finansowego, jakimi są banki spółdzielcze, a także historii bankowości spółdzielczej, jak, kiedy i dlaczego powstały, na jakich zasadach funkcjonują i co odróżnia je od innych podmiotów sektora bankowego. Dla realizacji wskazanego celu dokonano analizy dostępnej literatury naukowej, aktów prawnych, a także raportów i opracowań statystycznych z zakresu bankowości spółdzielczej.

\section{Początki spółdzielczości bankowej}

Prekursorami współczesnych banków spółdzielczych były tzw. banki pobożne, które powstały i upowszechniły się najpierw we Włoszech, kolebce bankowości, a następnie w innych częściach Europy. Pierwsza instytucja spółdzielni bankowej powstała w 1361 roku w Anglii. Korzystne warunki do rozwoju spółdzielczości pojawiły się dopiero w drugiej połowie XIX wieku. Zasadnicze przemiany polityczne i ekonomiczne w kraju, a przede wszystkim wsi, wpłynęły na poprawę sytuacji chłopów (wprowadzenie wolności osobistej i prawa własności użytkowej ziemi) przy jednoczesnym upowszechnianiu się gospodarki rynkowej. W obliczu bezbronności chłopi poszukiwali nie tylko metod ochrony własnych interesów, ale pod szyldem spółdzielni mogli się także zrzeszać w sposób legalny i zgodny z systemem prawnym zaborców ${ }^{1}$ (podłoże narodowe było wówczas specyficzną cechą polskiego ruchu spółdzielczego).

Do pierwszej wojny światowej spółdzielczość rozwijała się w każdym z trzech zaborów, ale w ramach odmiennych stosunków prawnych, politycznych i gospodarczych: banki ludowe w zaborze pruskim, towarzystwa zaliczkowe oraz kasy oszczędności i pożyczek (kasy Stefczyka) w zaborze austriackim oraz kasy pożyczkowe przemysłowców, towarzystwa wzajemnego kredytu, towarzystwa przemysłowo-oszczędnościowe (udziałowe) i towarzystwa kredytowe (bezudziałowe) w zaborze rosyjskim².

Wobec rozdrobnienia środowiska spółdzielczego i jego nierównomiernego rozmieszczenia na terenie kraju coraz liczniej pojawiały się głosy dotyczące potrzeby konsolidacji. Po raz pierwszy postulat ${ }^{3}$ zjednoczenia spółdzielni wysunął M. Łyskowski w 1870 roku w „Przewodniku dla spółek pożyczkowych”. Do idei unifikacji polskiego ruchu spółdzielczego powrócono ponownie po odzyskaniu niepodległości, kiedy to w lutym 1918 roku podczas zjazdu przedstawicieli wszystkich dziedzin spółdzielczości w Lublinie wskazano na konieczność ujednolicenia charakteru spółdzielczego. W następstwie tych wydarzeń w 1920 roku Sejm uchwalił ustawę o spółdzielniach ${ }^{4}$. Wzorowana na ustawie pruskiej,

\footnotetext{
${ }^{1}$ K. Stanisławski (red): Spółdzielczość bankowa, Wydawnictwo Czarno-Biała, Bydgoszcz 2000, s. 13.

${ }^{2}$ K. Stanisławski (red): Spółdzielczość bankowa 140 lat, Wydawnictwo Czarno-Biała, Bydgoszcz 2003, s. 6.

${ }^{3}$ K. Stanisławski (red.), 2003, op. cit., s. 30.

${ }^{4}$ Ustawa z dnia 29 października 1920 roku o spółdzielniach (Dz.U. 1920 nr 111, poz. 733).
} 
jak na owe czasy wnosiła do polskiego porządku prawnego wiele nowatorskich rozstrzygnięć oraz o wiele bardziej demokratyczny charakter.

Okres międzywojenny to nasilający się interwencjonizm państwa w działalności spółdzielni (poprzez akty prawne), wynikający jednakże z trudnej sytuacji ekonomicznej kraju. Osłabienie gospodarki wojną, brak trwałych struktur gospodarczych, inflacja, masowy odpływ ludności odcisnęły trwałe piętno na strukturach spółdzielczych i dopiero reforma walutowa Grabskiego w 1924 roku ustabilizowała wartość pieniądza, stwarzając warunki do rozwoju operacji kredytowych. Mimo niesprzyjających realiów spółdzielnie oszczędnościowo-pożyczkowe w okresie międzywojennym należały do najliczniejszych i gospodarczo najsilniejszych zrzeszeń spółdzielczych na ziemiach polskich ${ }^{5}$.

W okresie okupacji całkowicie zniszczono podstawy materialne spółdzielczości kredytowej ${ }^{6}$ - większość banków postawiono w stan likwidacji. Na terenach zajętych przez Rosjan spółdzielnie zlikwidowano lub włączono do systemu Centrosojuza7, a na terenach przyłączonych do Rzeszy majątek spółdzielni przejęły przedsiębiorstwa niemieckie. Jedynie na terenie tzw. Generalnej Guberni ${ }^{8}$ funkcjonowały polskie spółdzielnie kredytowe nadzorowane przez niemiecki Urząd Nadzoru Bankowego.

\section{Spółdzielczość bankowa w okresie powojennym (1945-1999)}

Okres powojenny to przede wszystkim działania zmierzające do reaktywowania dawnych spółdzielni oszczędnościowo-pożyczkowych (SOP) ${ }^{9}$ oraz rzadziej tworzenie nowych (zwykle organizowanych według przedwojennych statutów i zasad). Jednakże powojenny krajobraz nie sprzyjał budowie bankowości spółdzielczej - brak środków własnych i panująca bieda na wyniszczonych wojną ziemiach sprawiły, iż nierzadko członkowie spółdzielni nie dysponowali środkami pozwalającymi na wpłaty do banku. Jedynie nieliczne spółdzielnie bankowe posiadały własny majątek w postaci nieruchomości. Kolejnym problemem były znaczne ruchy migracyjne ludności. Osadnicy poszukując dla siebie miejsca, wielokrotnie osiedlali się i przejmowali w użytkowanie gospodarstwa, na uruchomienie których zaciągali kredyty, a następnie przenosili się na inne tereny, pozostawiając zapisaną im nieruchomość. Spółdzielnie oszczędnościowo-pożyczkowe były zrzeszone w tym okresie w Związku Rewizyjnym RP, zorganizowanym w 1944 roku w Lublinie, a ich centrale finansowe stanowiły kolejno: Centralna Kasa Spółek Rolni-

\footnotetext{
${ }^{5}$ K. Stanisławski (red.), 2003, op. cit., s. 33.

${ }^{6} \mathrm{M}$. Borycki (red.): Bankowość polska 1987-2012. Ludzie i ich dzieło, Centrum Prawa Bankowego i Informacji, Warszawa 2013, s. 126.

${ }^{7}$ Centrosoyuz of the Russian Federation: History, http://rus.coop/en/history (dostęp: 02.12.2018).

${ }^{8}$ Krajowy Związek Rewizyjny Spółdzielni Spożywców „Społem”, Spółdzielczość w Zaborach, http:// kzrss.spolem.org.pl/index.php/historia/spoldzielczosc-w-zaborach?showall=1\&limitstart= (dostęp: 02.12.2018).

${ }^{9}$ Bank Polskiej Spółdzielczości, https://www.bankbps.pl/o-grupie-bps/historia-bankowosci-spoldzielczej/spoldzielczosc-bankowa-w-okresie-powojennym (dostęp: 27.11.2018).
} 
czych $^{10}$ i Bank Spółdzielcy ,,Społem”11, a następnie Bank Gospodarstwa Spółdzielczego utworzony w wyniku fuzji obu wymienionych poprzednio central finansowych.

W 1950 roku minister skarbu na mocy dekretu o reformie bankowej ${ }^{12}$, w drodze zarządzenia, dokonuje przekształcenia części spółdzielni oszczędnościowo-pożyczkowych w gminne kasy spółdzielcze (GKS), których utworzono łącznie 1256. Zostały one podporządkowane organizacyjnie bankowi rolnemu, w ramach którego funkcjonowały przede wszystkim w obszarze finansowania skupu płodów rolnych. W następstwie przekształceń uległa ograniczeniu spółdzielczość bankowa zarówno w zakresie samodzielności, jak i samorządności. W porównaniu z rolniczymi spółdzielniami pożyczkowo-oszczędnościowymi gminne kasy spółdzielcze funkcję instytucji kredytowych sprawowały w ograniczonym zakresie. Pozbawiono je prawa przyjmowania na własny rachunek wkładów oszczędnościowych (pełniły funkcję pośrednika na rzecz PKO BP), a w zakresie kredytowym ograniczone zostały do udzielania pomocy mało- i średniorolnym chłopom. Szacuje się, iż było to głównym powodem spadku liczby spółdzielni bankowych z 1485 SOP w 1948 roku do 1256 GKS w 1950 roku (tj. o 229).

Kolejne lata (od 1956 r.) przyniosły diametralne zmiany w polityce rolnej (zwłaszcza wobec rolnictwa indywidualnego). Wzrosło znaczenie spółdzielczości bankowej, której między innymi przywrócono spółdzielczo-samorządowy charakter (wprowadzono także nowe powszechne nazewnictwo: „kasa spółdzielcza”) oraz powołano Związek SOP jako centralę organizacyjno-rewizyjną (spółdzielnie zyskały uprawnienia do udzielania pożyczek z własnych środków, udzielania zapomóg członkom oraz gromadzenia własnych wkładów oszczędnościowych na własny rachunek). W 1960 roku ustawą o prawie bankowym określono status SOP, zakres ich działalności oraz nadano uprawnienia do używania nazwy „,bank” z dodatkiem „,spółdzielczy” lub „ludowy”. Po odzyskaniu samodzielności i samorządności nastąpiło ożywienie działalności spółdzielni bankowych, wzrosła ich podstawowa działalność, tj. gromadzenie środków pieniężnych na rachunkach bankowych, co umożliwiało przeznaczanie części z nich na działalność kredytową, jak też umożliwiono spółdzielniom prowadzenie działalności rozliczeniowej. Do 1953 roku funkcję komórki rewizyjnej względem GKS pełnił bank rolny ${ }^{13}$, a następnie Narodowy Bank Polski. Odzyskanie samodzielności przez spółdzielnie, mimo że niepełne, ponieważ centralą finansową nadal był bank państwowy, działalność kredytowa podlegała planowaniu, a zwrot wkładów gwarantował Skarb Państwa - zaowocowało gwałtownym wzrostem liczby spółdzielni. O ile w 1956 roku było ich 1285, o tyle w 1960 już 1359, a w 1975 aż 1662.

\footnotetext{
${ }^{10}$ Statut Centralnej Kasy Spółek Rolniczych w Warszawie (Dz. Pr. P. P. 1919 nr 15 poz. 213).

${ }^{11}$ Krajowy Związek Rewizyjny Spółdzielni Spożywców „Społem”, Historia, http://kzrss.spolem.org.pl/ index.php/historia?showall=\&start=3 (dostęp: 02.12.2018).

${ }^{12}$ Dekret z dnia 25 października 1948 r. o reformie bankowej (Dz.U. 1948 nr 52, poz. 412).

${ }^{13}$ Encyklopedia PWN: hasło bank rolny, https://encyklopedia.pwn.pl/haslo/Bank-Rolny;3874086.html (dostęp: 27.11.2018).
} 
Lata 90. przyniosły kolejne zmiany. Przyjęcie ustawy w 1989 roku Prawo bankowe i o NBP ${ }^{14}$ doprowadziło do likwidacji związków spółdzielczych, a zrzeszanie się banków spółdzielczych z BGŻ stało się dobrowolne. W 1991 roku część banków, rezygnując z dotychczasowej współpracy z BGŻ, utworzyło Krajowy Związek Banków Spółdzielczych (KZBS), a następnie podjęło działania, których celem było utworzenie banków regionalnych. Jako pierwszy powstał Gospodarczy Bank Wielkopolski SA w Poznaniu, Gospodarczy Bank Południowo-Zachodni SA we Wrocławiu, a następnie Bank Unii Gospodarczej SA w Warszawie. Jednocześnie decyzją prezesa NBP zobowiązano wszystkie banki spółdzielcze do zrzeszenia się w jednej ze struktur zrzeszeniowych (BGŻ, KZBS, GBW, GBPZ, BUG).

Kolejnym krokiem reformy spółdzielczości bankowej było wprowadzenie w 1994 roku ustawy ${ }^{15}$ o restrukturyzacji banków spółdzielczych i BGŻ rozpoczynającej proces tworzenia trójszczeblowej struktury: banków spółdzielczych, banków zrzeszających oraz banku krajowego. Dwa pierwsze banki zrzeszające powstały w 1995 roku: Warmińsko-Mazurski Bank Regionalny SA w Olsztynie oraz Lubelski Bank Regionalny SA w Lublinie. Łącznie powołano 9 banków regionalnych z siedzibami w miejscowościach: Bydgoszcz, Koszalin, Kraków, Lublin, Olsztyn, Poznań, Rzeszów, Warszawa i Wrocław, w zrzeszeniach których w 1995 roku funkcjonowało 1510 banków spółdzielczych (największą liczbę banków spółdzielczych w okresie powojennym odnotowano w 1989 r. - 1662).

Kolejne lata, zwłaszcza po 1994 roku, były dla banków spółdzielczych okresem wzmożonych procesów łączeniowych. Narastająca konkurencja na rynku usług finansowych, a przede wszystkim wymogi w zakresie funduszy własnych ${ }^{16}$ skłoniły wiele banków do podjęcia decyzji o połączeniu sił i zasobów ${ }^{17}$. Od 1993 do 1999 roku liczba banków spółdzielczych zmalała z 1653 do 781. Ministerstwo Finansów w odpowiedzi ${ }^{18}$ podsekretarza stanu w 2000 roku oceniło efekty procesów konsolidacyjnych następująco: „Efektem konsolidacji jest nie tylko wzrost przeciętnych, podstawowych wielkości (suma bilansowa, zatrudnienie, fundusze własne), ale również to, że sektor ten staje się o wiele mniej zróżnicowany niż sektor banków komercyjnych. Pozwala to sformułować wniosek, iż banki spółdzielcze nabierają charakteru klasycznej, jednorodnej grupy silnych banków lokalnych znanych w krajach UE, których jednym z zadań jest dostarczanie środków do systemu bankowego (64,5\% depozytów sektora niefinansowego i budże-

\footnotetext{
${ }^{14}$ Ustawa z dnia 31 stycznia 1989 r. Prawo bankowe (Dz.U. 1989 nr 4, poz. 21).

${ }^{15}$ Ustawa z dnia 24 czerwca 1994 r. o restrukturyzacji banków spółdzielczych i Banku Gospodarki Żywnościowej oraz o zmianie niektórych ustaw (Dz.U. 1994 nr 80, poz. 59).

${ }^{16}$ Uchwała nr 9/98 Komisji Nadzoru Bankowego z dnia 5 sierpnia 1998 r. w sprawie szczegółowych zasad wyposażenia banków spółdzielczych w kapitał założycielski (Dz.U. NBP nr 19/1998, poz. 44).

${ }^{17}$ W 1989 roku w Polsce funkcjonowały 1662 banki spółdzielcze, wskutek zmian regulacyjnych i organizacyjnych liczba ta uległa zmniejszeniu do 575 banków na koniec 2011 roku - A. Rosa: Konsolidacja sektora bankowości spółdzielczej w Polsce, Zeszyty Naukowe Uniwersytetu Szczecińskiego, Finanse, Rynki finansowe, Ubezpieczenia 2012, nr 51, s. 831.

${ }^{18}$ K.J. Ners: Odpowiedź podsekretarza stanu w Ministerstwie Finansów (z upoważnienia ministra) na interpelację nr 4386 w sprawie zasad obowiązywania progów kapitałowych dla banków spółdzielczych, Ministerstwo Finansów, Warszawa 2000.
} 
towego było zaangażowanych w działalności kredytowej w końcu 1999 r., a w bankach komercyjnych zaangażowanie to wynosiło 73,3\%). Należy zauważyć, iż wraz ze zmniejszeniem się liczby banków rośnie liczba ich placówek, co dowodzi, że możliwości obsługi klientów, a zwłaszcza rolników indywidualnych, ulegają poprawie".

\section{Funkcjonowanie banków spółdzielczych po 1999 roku}

Współcześnie polskie banki spółdzielcze należą do najliczniejszej i najbardziej zróżnicowanej pod względem organizacyjnym, prawnym i finansowym grupy banków funkcjonujących w Europie. Jest to także grupa najszybciej rozwijających się segmentów sektora bankowego i rynku finansowego. Dzięki stabilnym podstawom (liczna grupa pojedynczych banków tworzących całą strukturę) oraz silnym więziom członków (udziałowców), tworzących podstawy sprawnego funkcjonowania struktur organizacyjnych, banki spółdzielcze na trwałe wpisały się w krajobraz polskiego rynku finansowego jako banki uniwersalne, świadczące szeroki i różnorodny zakres usług ${ }^{19}$.

Banki spółdzielcze odgrywają ważną rolę w systemach bankowych w wielu krajacheuropejskich ${ }^{20}$ i choć nie wywołały kryzysu i nie były jego siłą napędową, to w pewnym stopniu odczuły jego skutki ${ }^{21}$. W porównaniu z dużymi bankami komercyjnymi okazały się bardziej odporne na kryzys i wpłynęły stabilizująco na system finansowy kraju. Wpłynęły na to takie elementy, jak: prosty i przejrzysty model biznesowy, wystarczające wyposażenie w kapitał własny, zasada ograniczenia obszaru działania do regionu ${ }^{22}$, konserwatywny system zarządzania ryzykiem i dobry system ochrony depozytów.

Na koniec marca 2018 roku działały w Polsce 552 banki spółdzielcze ${ }^{23}$, z czego 352 (63\%) ogółu banków spółdzielczych było zrzeszonych w BPS SA w Warszawie, a 198 (37\%) ogółu banków spółdzielczych w SGB-Banku SA w Poznaniu. Poza zrzeszeniami działają24. Krakowski Bank Spółdzielczy, Bank Spółdzielczy w Brodnicy, Bank Spółdzielczy Rzemiosła w Krakowie, Warmińsko-Mazurski Bank Spółdzielczy w Piszu, Wielkopolski Bank Spółdzielczy w Poznaniu i Polski Bank Spółdzielczy w Ciechanowie. Spośród 552 banków spółdzielczych 488 banków było uczestnikami instytucjonalnych systemów ochrony (293 ze zrzeszenia BPS, 195 ze zrzeszenia SGB). Poza instytucjonalnymi sys-

\footnotetext{
${ }^{19}$ E. Nastarowicz (red.): Bankowość spółdzielcza - wyróżniki, misja, wartości, Centrum Prawa Bankowego i Informacji, Warszawa 2017, s. 6.

${ }^{20} E$. Gostomski: Europejskie banki spółdzielcze jako czynnik stabilizacji systemów bankowych w dobie globalnego kryzysu finansowego, Prace Naukowe Wyższej Szkoły Bankowej w Gdańsku, Uniwersytet Gdański, Wyższa Szkoła Bankowa w Gdańsku, Gdańsk 2011.

${ }^{21}$ Urząd Komisji Nadzoru Finansowego: Polski rynek finansowy w obliczu kryzysu finansowego w latach 2008-2009, Warszawa 2010.

${ }^{22}$ W. Baka: Transformacja bankowości polskiej w latach 1988-95, Biblioteka Menedżera i Bankowca, Warszawa 1997.

${ }^{23}$ Komisja Nadzoru Finansowego: Raport: Banki spółdzielcze i zrzeszające w I kw. 2018 r., [w:] Informacja o sytuacji banków spółdzielczych i zrzeszających w I kwartale 2018 r., Wydział Analiz i Metodyk Departamentu Bankowości Spółdzielczej i Spółdzielczych Kas Oszczędnościowo-Kredytowych, Warszawa 2018.

${ }^{24}$ Według stanu na 03.12.2018 r.
} 
temami ochrony (IPS - ang. institutional protection scheme) funkcjonowały 64 banki spółdzielcze. W ramach tych systemów działa 88,4\% wszystkich banków spółdzielczych, a IPS dysponuje 81,1\% aktywów sektora banków spółdzielczych.

Aktywa banków spółdzielczych stanowiły 9,5\% aktywów sektora bankowego, depozyty sektora niefinansowego 10,2\%, należności od sektora niefinansowego 7,2\%. Warto zwrócić uwagę na znaczenie sektora spółdzielczego w obsłudze samorządów: duży udział w depozytach $(27,6 \%)$ oraz rosnący udział w kredytach $(24,7 \%)$. Jak zwraca uwagę nadzorca krajowy, należności od samorządów bardzo silnie wzrosły począwszy od czwartego kwartału 2017 roku, co świadczy o rosnącym zapotrzebowaniu na kredyt z ich strony. W dalszym ciągu jednak - w dłuższej perspektywie czasowej, w porównaniu np. do końca 2015 roku - najsilniej rosną należności od osób prywatnych. Oba zjawiska świadczą o próbie przeorientowania polityki kredytowej przez banki spółdzielcze. Zwłaszcza wzrost liczby kredytów dla osób prywatnych jest obserwowany od dłuższego czasu i może świadczyć o zwiększającym się zainteresowaniu banków spółdzielczych tym rynkiem. Banki te wciąż jednak zainteresowane są finansowaniem działalności gospodarczej (kredyty na ten cel stanowią ok. 75\% należności od sektora niefinansowego), na co wpływ niewątpliwie ma tradycja banków spółdzielczych, gdyż zostały utworzone właśnie w celu finansowania działalności rolników i rzemieślników.

Na koniec marca 2018 roku liczba udziałowców banków spółdzielczych wyniosła 962 tys. osób (w tym 959 tys. to osoby fizyczne) i od momentu pierwszego badania ankietowego (tj. od marca 2012 r.) obniżyła się o ponad 105 tys. osób (w tym o ponad 104 tys. osób fizycznych). Łączny współczynnik kapitałowy banków spółdzielczych wyniósł 17,8\% (wobec 19,0\% dla banków komercyjnych), zaś współczynnik Tier 1 wyniósł $16,1 \%$ wobec $16,3 \%$ w grudniu 2017 roku.

Zatrudnienie w bankach spółdzielczych od 2012 roku sukcesywnie maleje, jednakże udział pod względem zatrudnienia w sektorze bankowym wyniósł na koniec pierwszego kwartału 2018 roku 19,9\%. Udział zatrudnienia w sektorze bankowości spółdzielczej w porównaniu do sektora bankowego ogółem jest dwukrotnie większy niż udział aktywów sektora spółdzielczego w aktywach sektora bankowego ogółem, a placówki banków spółdzielczych (łącznie z centralami) stanowią 41,1\% liczby placówek bankowych w Polsce.

Rozbudowana struktura oraz zatrudnienie wpływa negatywnie na wyniki efektywności banków spółdzielczych - udział wyniku finansowego netto w sektorze bankowym wyniósł zaledwie $6,4 \%$. Wskaźnik C/I banków spółdzielczych ogółem ukształtował się na poziomie $65,1 \%$ (banki komercyjne $60 \%$ ), ROA na poziomie 0,6\% (banki komercyjne $0,8 \%$ ), a ROE 6,8\% (banki komercyjne 6,7\%).

Od 2015 roku w Polsce funkcjonują IPS utworzone na podstawie rozporządzenia ${ }^{25}$ Parlamentu Europejskiego i Rady 575/2013 oraz ustawy z 2015 roku o zmianie usta-

\footnotetext{
${ }^{25}$ Rozporządzenie Parlamentu Europejskiego i Rady (UE) nr 575/2013 z dnia 26 czerwca 2013 r. w sprawie wymogów ostrożnościowych dla instytucji kredytowych i firm inwestycyjnych, zmieniające rozporządzenie (UE) nr 648/2012 (Capital Requirements Regulation, CRR) oraz Dyrektywa Parlamentu Europejskiego i Rady 2013/36/UE z dnia 26 czerwca 2013 r. w sprawie warunków dopuszczenia instytucji kredytowych do działalności oraz nadzoru ostrożnościowego nad instytucjami kredytowymi i fir-
} 
wy o funkcjonowaniu banków spółdzielczych ${ }^{26}$, ich zrzeszaniu się i bankach zrzeszających oraz niektórych innych ustaw. Pierwsza umowa ${ }^{27}$ o utworzeniu IPS podpisana została przez 191 banków spółdzielczych zrzeszenia SGB oraz SGB-Bank SA 23 listopada 2015 roku. Druga umowa została podpisana przez 241 banków spółdzielczych zrzeszenia BPS oraz BPS SA 31 grudnia 2015 roku.

Istotą systemów ochrony jest wspólna odpowiedzialność uczestników - każdy uczestnik systemu ochrony odpowiada za zobowiązania wynikające z gwarantowania płynności i wypłacalności pozostałych uczestników IPS - do wysokości funduszy pomocowych, a wyniki kompleksowego przeglądu sytuacji i ryzyka każdego oraz wszystkich łącznie uczestników są udostępniane poszczególnym członkom.

Od początku powstania IPS uczestnicy gromadzili środki na rachunkach depozytu obowiązkowego w bankach zrzeszających oraz funduszach pomocowych. Celem depozytu obowiązkowego jest zabezpieczenie płynności uczestników IPS, zaś funduszu pomocowego wsparcie w przypadku trudnej sytuacji ekonomicznej (w tym w obszarze adekwatności kapitałowej). Wartość depozytu obowiązkowego banków IPS zrzeszonych w BPS SA wynosiła na koniec marca 2018 roku 5,1 mld zł. Środki zgromadzone w funduszu pomocowym IPS BPS na koniec pierwszego kwartału 2018 roku wynosiły 431,4 mln zł. Wartość depozytu obowiązkowego utrzymywanego przez banki spółdzielcze IPS SGB oraz SGB-Bank SA wyniosła 1,9 mld zł.

W kontekście IPS należy również wspomnieć o nowym zrzeszeniu - pierwotnie 56 banków spółdzielczych zadeklarowało chęć założenia nowego zrzeszenia, jednakże do aktu notarialnego o utworzeniu nowego banku zrzeszającego przystąpiło 47 banków, w tym jeden będący uczestnikiem IPS BPS, zaś cztery inne zadeklarowały wycofanie się z tej inicjatywy. Jednakże Komisja Nadzoru Finansowego 27 listopada 2018 roku odmówiła $^{28}$ wydania zezwolenia na rozpoczęcie działalności przez Polski Bank Apeksowy SA.

\section{Podsumowanie}

Bankowość spółdzielcza funkcjonuje w Polsce od ponad 150 lat i jest nieodłącznym elementem społeczności lokalnej. Oferta banków spółdzielczych uwzględnia różne potrzeby i możliwości gospodarczo-ekonomiczne poszczególnych regionów kraju. Z racji bliskości i znajomości swoich klientów banki spółdzielcze pomagają i szybko podejmują decyzje, łączą tradycję z nowoczesnością, oferując klasyczne rozwiązania z elementami nowoczesnych technologii (np. z zakresu bankowości biometrycznej, płatności zbliżenio-

mami inwestycyjnymi, zmieniająca dyrektywę 2002/87/WE i uchylająca dyrektywy 2006/48/WE oraz 2006/49/WE (Capital Requirements Directive IV, CRD IV), (OJ L 176/1 z 27.06.2013).

${ }^{26}$ Ustawa z dnia 25 czerwca 2015 r. o zmianie ustawy o funkcjonowaniu banków spółdzielczych, ich zrzeszaniu się i bankach zrzeszających oraz niektórych innych ustaw (Dz.U. 2015, poz. 1166).

${ }^{27}$ Urząd Komisji Nadzoru Finansowego: Informacja o sytuacji banków spółdzielczych i zrzeszających w I kwartale 2018 r., Wydział Analiz i Metodyk Departamentu Bankowości Spółdzielczej i Spółdzielczych Kas Oszczędnościowo-Kredytowych, Warszawa 2018, s. 16.

${ }^{28}$ Komisja Nadzoru Finansowego: Komunikat KNF z dnia 27.11.2018 r. ws. odmowy wydania zezwolenia na rozpoczęcie działalności przez Polski Bank Apeksowy S.A., https://www.knf.gov.pl/o_nas/komunikaty?articleld=63928\&p_id=18 (dostęp: 27.11 .2018$)$. 
wych czy przelewów natychmiastowych). Realizują postanowienia ekonomii społecznej - są bardziej odporne na kryzys, zapewniają bezpieczne zatrudnienie (także w okresach spowolnienia gospodarczego), pomagają przezwyciężać biedę, gospodarczą stagnację i wykluczenie ekonomiczne. Będąc głównym źródłem kredytowania gospodarstw domowych i sektora MŚP, stymulują rozwój regionów, w których działają, a wypracowane i pozyskane środki reinwestują na poziomie lokalnym, co wpływa na stabilizację gospodarki narodowej.

\section{Literatura}

Baka W.: Transformacja bankowości polskiej w latach 1988-95, Biblioteka Menedżera i Bankowca, Warszawa 1997.

Bank Polskiej Spółdzielczości: Spółdzielczość bankowa w okresie powojennym, https://www.bankbps. pl/o-grupie-bps/historia-bankowosci-spoldzielczej/spoldzielczosc-bankowa-w-okresie-powojennym (dostęp: 27.11.2018).

Borycki M.: Bankowość polska 1987-2012, [w:] Ludzie i ich dzieło, M. Borycki (red.), Centrum Prawa Bankowego i Informacji, Warszawa 2013.

Centrosoyuz of the Russian Federation: History, http://rus.coop/en/history (dostęp: 02.12.2018).

Dekret z dnia 25 października 1948 r. o reformie bankowej (Dz.U. $1948 \mathrm{nr}$ 52, poz. 412).

Encyklopedia PWN: hasło bank rolny, https://encyklopedia.pwn.pl/haslo/Bank-Rolny;3874086.html (dostęp: 27.11.2018).

Gostomski E.: Europejskie banki spółdzielcze jako czynnik stabilizacji systemów bankowych w dobie globalnego kryzysu finansowego, Prace Naukowe Wyższej Szkoły Bankowej w Gdańsku, Uniwersytet Gdański, Wyższa Szkoła Bankowa w Gdańsku, Gdańsk 2011.

Komisja Nadzoru Finansowego: Informacja o sytuacji banków spółdzielczych i zrzeszających w I kwartale 2018 r., Wydział Analiz i Metodyk Departamentu Bankowości Spółdzielczej i SKOK, Warszawa 2018.

Komisja Nadzoru Finansowego: Komunikat KNF z dnia 27.11.2018 r. ws. odmowy wydania zezwolenia na rozpoczęcie działalności przez Polski Bank Apeksowy S.A., https://www.knf.gov.pl/o_nas/ komunikaty?articleld=63928\&p_id=18(dostęp: 02.12.2018).

Komisja Nadzoru Finansowego: Raport. Banki spółdzielcze i zrzeszające w I kw. 2018 r., [w:] Informacja o sytuacji banków spółdzielczych i zrzeszających w I kwartale 2018 r., Wydział Analiz i Metodyk Departamentu Bankowości Spółdzielczej i SKOK, Warszawa 2018.

Krajowa Rada Spółdzielcza, Historia bankowości spółdzielczej w Polsce, https://www.krs.org.pl/index.php/ruch-spodzielczy-sp-1235027509/brane-spodzielcze/banki-spodzielcze (dostęp: 01.12.2018).

Krajowy Związek Rewizyjny Spółdzielni Spożywców „Społem”, Historia, http://kzrss.spolem.org.pl/index.php/historia?showall=\&start=3 (dostęp: 02.12.2018).

Krajowy Związek Rewizyjny Spółdzielni Spożywców „Społem”, Spółdzielczość w Zaborach, http://kzrss. spolem.org.pl/index.php/historia/spoldzielczosc-w-zaborach?showall=1\&limitstart= (dostęp: 02.12.2018).

Łyskowski M.: Przewodnik spółek pożyczkowych, 1870.

Nastarowicz E. (red.): Bankowość spółdzielcza - wyróżniki, misja, wartości, Centrum Prawa Bankowego i Informacji, Warszawa 2017.

Ners K.J.: Odpowiedź podsekretarza stanu w Ministerstwie Finansów (z upoważnienia ministra) na interpelację nr 4386 w sprawie zasad obowiązywania progów kapitałowych dla banków spółdzielczych, Ministerstwo Finansów, Warszawa 2000. 
Potocki W. (red.): Polska spółdzielczość bankowa w okresie 135-lecia (1861-1996), BGŻ, Warszawa 1996.

Rosa A: Konsolidacja sektora bankowości spółdzielczej w Polsce, Zeszyty Naukowe Uniwersytetu Szczecińskiego, Finanse, Rynki finansowe, Ubezpieczenia 2012, nr 51, s. 831.

Rozporządzenie Parlamentu Europejskiego i Rady (UE) nr 575/2013 z dnia 26 czerwca 2013 r. w sprawie wymogów ostrożnościowych dla instytucji kredytowych i firm inwestycyjnych, zmieniające rozporządzenie (UE) nr 648/2012 (Capital Requirements Regulation, CRR) oraz Dyrektywa Parlamentu Europejskiego i Rady 2013/36/UE z dnia 26 czerwca 2013 r. w sprawie warunków dopuszczenia instytucji kredytowych do działalności oraz nadzoru ostrożnościowego nad instytucjami kredytowymi i firmami inwestycyjnymi, zmieniająca dyrektywę 2002/87/WE i uchylająca dyrektywy 2006/48/WE oraz 2006/49/WE (Capital Requirements Directive IV, CRD IV), (OJ L 176/1 z 27.06.2013).

Stanisławski K. (red.): Spółdzielczość bankowa 140 lat, Wydawnictwo Czarno-Biała, Bydgoszcz 2003.

Stanisławski K. (red.): Spółdzielczość bankowa, Wydawnictwo Czarno-Biała, Bydgoszcz 2000.

Statut Centralnej Kasy Spółek Rolniczych w Warszawie (Dz. Pr. P. P. z 1919 nr 15, poz. 213).

Uchwała nr 9/98 Komisji Nadzoru Bankowego z dnia 5 sierpnia 1998 r. w sprawie szczegółowych zasad wyposażenia banków spółdzielczych w kapitał założycielski (Dz.U. NBP nr 19/1998, poz. 44).

Urząd Komisji Nadzoru Finansowego: Polski rynek finansowy w obliczu kryzysu finansowego w latach 2008-2009, Warszawa 2010.

Ustawa z dnia 24 czerwca 1994 r. o restrukturyzacji banków spółdzielczych i Banku Gospodarki Żywnościowej oraz o zmianie niektórych ustaw (Dz.U. 1994 nr 80, poz. 369).

Ustawa z dnia 25 czerwca 2015 r. o zmianie ustawy o funkcjonowaniu banków spółdzielczych, ich zrzeszaniu się i bankach zrzeszających oraz niektórych innych ustaw (Dz.U. 2015, poz. 1166).

Ustawa z dnia 29 października 1920 r. o spółdzielniach (Dz.U. 1920 nr 111, poz. 733).

Ustawa z dnia 31 stycznia 1989 r. Prawo bankowe (Dz.U. 1989 nr 4, poz. 21).

Węcławski J.: System bankowy w Polsce, MIG, Rzeszów 2000.

\section{The development of cooperative banking in Poland}

Summary. The oldest branch of cooperatives in Poland (banking) has been in operation since 1861. It was created from initiatives of the clergy to improve the situation of peasants and protect their interests and fight against economic exploitation and usury. During the partitions, gathering members in their ranks, apart from economic goals, it also supported the defense and strengthening of Polishness. It gradually developed until the outbreak of the World War I, a bit slower in the period of the revival of Poland and the interwar period. World War II brought about the liquidation of cooperatives and their estates and only after the war, profound economic and legal reforms enabled their resurgence, which lasted until the 1970s, when centralization again forced the sector to change. The 1990s are the new legal basis for the construction of a modern banking system in Poland, however, it was paid for by numerous consolidations and a drastic decrease in the number of cooperative banks. Nowadays, banking cooperatives are struggling with increasing capital and technological requirements as well as increasing competition and choosing the right business model. Despite the passage of years, it is still up-to-date and compared to other entities it has proved more resilient to the global financial crisis and has had a stabilizing effect on the country's financial system.

Key words: cooperative bank, cooperative banking history, savings and loan cooperative, credit cooperative 